\title{
ANALISIS KINERJA KEUANGAN KOPERASI SIMPAN PINJA PADA KOPERASI SUKA DAMAI
}

\author{
Adrianus Tolong ${ }^{1)}$ Husain As $^{2)}$ Sri Rahayu ${ }^{3)}$ \\ Sekolah Tinggi Keguruan Dan Ilmu Pendidikan Pembangunan Indonesia \\ Email : ayualmeaa@yahoo.co.id
}

\begin{abstract}
ABSTRAK
Penelitian ini bertujuan untuk untuk mengetahui kinerja keuangan KSP Suka Dami tahun 2013 - 2017 dengan mengunakan rasio likuiditas, Solvabilitas dan Rasio Rentabilitas. Penelitian ini dilakukan di Koperasi simpan Pinjam Suka Damai Kecamatan Macang Pacar kabupaten Manggarai Barat Pada bulan Juli Sampai bulan Agustus 2018. Obyek yang digunakan dalam penelitian ini adalah analisis kinerja keuangan selama limatahun sebelum 2013-2017 Koperasi Simpan Pinjam Sukadamai di Desa Pacar.Yang menjadi populasi dalam penelitian ini adalah keseluruhan laporan keuangan dari koperasi Suka Damai. Sampel adalah Sebagian dari laporan keuangan dari koperasi. Suka Damai yang menjadi populasi disini adalah: laporan keuangan di tahun 2013-2017. Metode analisis data pada laporan keuangan yang digunakan untuk mengukur, mengetahui, menggambarkan, menentukan serta membandingkan proporsi pada pos-pos dalam laporan neraca, laba rugi dan arus kas. hasil penelitian ini yaitu tahun 2013 sampai tahun2017 pada umumnya baik artinya sudah memenuhi kriteria yang sangat bagus Perkembangan rasio likuiditas, solvabilitas, profitabilitas pada KSP Suka Damai dari tahun 2013 sampai tahun 2017
\end{abstract}

Kata Kunci: koperasi , Kinerja Keuangan

\begin{abstract}
KSP Suka Dami in 2013 - 2017 by using liquidity ratios, solvency and profitability ratios. This research was conducted at the Savings and Loans Cooperative in Damai Macang Pacar District, West Manggarai district in July to August 2018. The object used in this study was an analysis of financial performance for the years before 2013-2017 Sukadamai Savings and Loans Cooperative in Pacar Village. in this study are financial reports from the Suka Damai cooperative. The sample is a part of the financial statements of the cooperative. Like Peace that is part here is: financial statements in 2013-2017. Data analysis methods on financial statements that are used to measure, find out, evaluate, determine and compare items on statements, income and cash flow. the results of this study in 2013 to 2017 generally generally means that there has been a very good assessment The development of liquidity ratios, solvency, profitability in the KSP Suka Damai from 2013 to 2017
\end{abstract}

Keywords: cooperatives, financial performance 


\section{PENDAHULUAN}

Perkembangan dan pertumbuhan koperasi selama ini belum sepenuhnya menampakkan wujud dan peranannya.Sampai kini sektor swasta masih mendominasi sektor perekonomian di Indonesia dan sektor koperasi konstribusinya terhadap perekonomian di Indonesia berada dilini terakhir. Oleh karena itu, dalam rangka menggalang dan memperkokoh perekonomian rakyat, koperasi harus berusaha sekuat tenaga agar memiliki kinerja usaha yang tangguh dan efisien. Sebab hanya dengan cara itulah koperasi dapat menjalankan perekonomian rakyat sebagai dasar kekuatan dan ketahanan perekomomian nasional (Baswir, 2013).

Menurut Undang-Undang Nomor 25 Tahun 1992 tentang perkoperasian, "Koperasi adalah badan usaha yang beranggotakan orang-orang atau badan hukum koperasi dengan melandaskan kegiatannya berdasarkan prinsip koperasi sekaligus sebagai gerakan ekonomi rakyat yang berdasarkan atas asaskekeluargaan.Lembaga koperasi sejak awal diperkenalkan di Indonesia memang sudah diarahkan untuk berpihak kepada kepentingan ekonomi rakyat yang dikenal sebagai golongan ekonomi lemah. Strata ini biasanya berasal dari kelompok masyarakat kelas menengah ke bawah. Eksistensi koperasi memang merupakan suatu fenomena tersendiri, sebab tidak satu lembaga sejenis lainnya yang mampu menyamainya, tetapi sekaligus diharapkan menjadi penyeimbang terhadap pilar ekonomi lainnya. Pada umumnya koperasi juga memerlukan suatu alat yang dapat digunakan untuk mengetahui kinerja keuangan koperasi agar manajemen dari pihak koperasi dapat melaksanakan tugas dan kewajibannya dengan baik sesuai dengan tujuan koperasi pada umumnya.

Koperasi merupakan salah satu bentuk organisasi ekonomi yang sedang mendapatkan perhatian pemerintah. Koperasi merupakan organisasi yang berbadan hukum. Pembangunan koperasi di Indonesia merupakan bagian dari usaha pembangunan nasional secara keseluruhan. Koperasi harus dibangun untuk menciptakan usaha dan pelayanan dalam menciptakan azas kekeluargaan.

Koperasi adalah usaha yang sesuai dengan demokrasi ekonomi, karena didalam demokrasi ekonomi terdapat unsur-unsur usaha koperasi. Sebagai pedoman umum dalam mengetahui kinerja keuangan, maka diperlukan laporan keuangan yang diterbitkan oleh koperasi, sehingga dapat diketahui keberhasilan maupun permasalahan yang dicapai koperasi dalam pengelolaan keuangannya. Pada hakikatnya laporan keuangan merupakan suatu daftar finansial yang berkaitan langsung dengan posisi keuangan dan operasi keuangan, yang keduanya memberikan informasi berkenaan dengan kondisi keuangan koperasi. Dalam pengukuran posisi keuangan, unsur yang berkaitan langsung adalah aktiva, kewajiban dan ekuitas. Sebaliknya unsur yang berkaitan dengan pengukuran operasi keuangan adalah pendapatan dan biaya, yang tercermin dalam laba/rugi bersih koperasi.Analisis laporan keuangan mencakup pengaplikasian berbagai alat dan teknik analisis pada laporan dan data keuangan dalam rangka untuk memperoleh ukuran dan hubungan yang berarti dan berguna dalam proses pengambilan keputusan Dengan demikian tujuan analisis laporan keuangan adalah mengkonversikan data menjadi informasi.Ada beberapa tujuan yang ingin dicapai dalam analisis laporan keuangan misalnya sebagai alat forecasting mengenai kondisi dan kinerja keuangan di masa mendatang. Ada beberapa 
teknik yang biasanya digunakan dalam melakukan suatu analisis, dimana salah satunya adalah analisis rasio.

Tujuan koperasi yang telah dikemukakan tersebut mendorong didirikannya Koperasi Simpan Pinjam Sukadami yang ada di Desa Pacar Kecamatan Macang Pacar Kabupaten Manggarai Barat.

Koperasi Simpan Pinjam Sukadami telah membantu masyarakat menengah ke bawah untuk dapat memperoleh dana/pinjaman dengan mudah, modal usaha, pendidikan, kesehatan dan lain-lain. Koperasi Simpan Pinjam Sukadami melakukan penghimpunan dana dari para anggota dalam bentuk simpan pokok, wajib, cadangan, dan donasi. Dana yang dihimpun akan dipergunakan untuk meningkatkan permodalan yang nantinya akan disalurkan kepada anggota dalam bentuk kredit. Kredit tersebut pada umumnya dipergunakan oleh anggota untuk modal kerja atau konsumsi. Melalui kegiatan ini Koperasi Simpan Pinjam Sukadamai memperoleh SHU (Sisa Hasil Usaha) yang dibagikan kepada para anggotanya setiap akhir tahun.

Berdasarkan laporan keuangan yang telah ada, pada tahun 2013 sampai 2017 terjadi peningkatan pada aktiva lancar, aktiva tetap, kewajiban lancar, kewajiban jangka panjang dan modal sendiri namun masih berfluktuasi SHU.Koperasi Simpan Pinjam Sukadami sehingga belum diketahui bagaimana perkembangan laporan keuangan yang terjadi pada kinerja keuangan Koperasi Simpan Pinjam Suka Damai tersebut, maka dari itu perlu dilakukan analisis agar tidak memberikan informasi yang semu. Sebagai salah satu badan usaha, koperasi harus bisa mengontrol penggunaan modal dalam koperasinya agar dapat meningkatkan efisiensi hasil koperasi. Keberhasilan dalam penggunaan modal, dapat dilihat dari rentabilitas koperasi.

\section{METODE PENELITIAN}

Penelitian ini dilakukan di Koperasi simpan Pinjam Suka Damai Kecamatan Macang Pacar kabupaten Manggarai Barat Pada bulan Juli Sampai bulan Agustus 2018. Obyek yang digunakan dalam penelitian ini adalah analisis kinerja keuangan selama limatahun sebelum 2013-2017 Koperasi Simpan Pinjam Suka damai di Desa Pacar.Yang menjadi populasi dalam penelitian ini adalah: keseluruhan laporan keuangan dari koperasi Suka Damai. Sampel adalah: Sebagian dari laporan keuangan dari koperasi. Suka Damai yang menjadi populasi disini adalah: laporan keuangan di tahun 2013-2017.

Metode analisis data pada laporan keuangan yang digunakan untuk mengukur, mengetahui, menggambarkan, menentukan serta membandingkan proporsi pada pospos dalam laporan neraca, laba rugi dan arus kas. Analisis rasio merupakan metode analisis yang digunakan dengan menganalisis laporan keuangan pada tahun (periode) tertentu, yaitu dengan membandingkan antara pos yang satu dengan pos lainnya dalam laporan keuangan yang sama dengan tahun yang sama. Dalam menganalisis rasio keuangan, sebagai standar dalam menilai kinerja keuangan pada penelitian ini digunakan standar yang telah ditetapkan berdasarkan Keputusan Menteri Negara Koperasi dan UKM No.06/Per/M/KUKM/V/2006 tentang Standar Penilaian Kesehatan, ada tiga kelompok rasio (likuiditas, solvabilitas, profitabilitas ) dihitung 
dari data laporan neraca dan rugi laba, kemudian ditabulasi berdasarkan masingmasing rasio dan tahun tanpa uji statistik.

Adapun cara menilai kinerja keuangan dengan Analisis rasio yang terbagi dari tiga kelompok sebagai berikut:

1. Rasio likuiditas

Rasio lancar (current ratio), dihitung dengan cara membagi aktiva lancer dengan kewajiban lancar dengan rumus sebagai berikut ;

$$
\text { current ratio }=\frac{\text { aktiva lancar }}{\text { hutang lancar }} \times 100 \%
$$

Keterangan:

Current ratio adalah : perbandingan antara jumlah aktiva lancar dengan hutang lancar

Aktiva Lancar adalah : aset yang dapat digunakan dalam jangka pendek.

Hutang Lancar adalah : hutang yang diharapkan perusahaan akan dibayar dalam jangka waktu satu tahun.yang termasuk dalam hutang lancar yaitu hutang dagang,hutangwesel,hutang pajak penjualan dan pendapatan diterima di muka

Kriteria current ratio yang digunakan yaitu:

Sangat baik $=200 \%-250 \%$

Baik $=175 \%-<200 \%$

Cukup baik $=150 \%-<175 \%$

Kurang baik $=125 \%-<150$

Buruk $=125 \%$

2. Rasio solvabilitas

Total Debt to Total Assets Ratio, dihitung dengan cara membagi total hutang dengan total aktiva.

Keterangan

$$
\text { Debt ratio }=\frac{\text { Total Hutang }}{\text { Total Aktiva }} \times 100 \%
$$

Debet ratio adalah : Rasio yang digunakan untuk mengukur seberapa besar perusahaan mengadalkan hutang untuk membiayai asetnya.

Total Hutang adalah : sumber dana atau modal perusahaan yang kereditor.

Total Aktiva adalah : penjumlahan dari aktiva lancar dan aktiva tetap yang merupakan harta perusahaan secara keseluruhan.

Kriteria total debt to total asset ratio yang digunakan yaitu:

Sangat baik $=<40 \%$

Baik $=40 \%-<50 \%$

Cukup baik $=50 \%-<60 \%$

Kurang baik $=60-<80 \%$

Buruk $=>80 \%$

3. Rasio rentabilitas 
Tingkat pengembalian ekuitas (return on equity-ROE), dihitung dengan membagi laba bersih dengan ekuitas.

Keterangan

$$
\text { return on equity }=\frac{\text { Sisa Hasil Usaha }}{\text { Modal Sendiri }} \times 100 \%
$$

Return on eguity adalah : Salah satu rasio keuangan yang menunjukan tingkat efektivitas tim manajemen perusahaan dalam menghasilkan laba dana yang $\mathrm{d}$ investasikan pemegang saham.

Sisa Hasil usaha adalah : Pendapatan yang dihasilkan oleh koperasiyangdiperoleh dalam satu tahun

Modal Sendiri $\quad$ : Modal yang berasal dari pemilik perusahaan dan yang tertanam di dalam perusahaan

Kriteria $R O E$ yang digunakan yaitu:

Sangat baik $=21 \%$

$\begin{aligned} \text { Baik } & =15 \%-<21 \% \\ \text { Cukup baik } & =10 \%-<15 \% \\ \text { Kurang baik } & =3 \%-<10 \% \\ \text { Buruk } & =<3 \%\end{aligned}$

\section{HASIL DAN PEMBAHASAN}

\section{A. Hasil Penelitian}

1. Jumlah Anggota

Sampai akhir tahun 2013 anggota yang terdaftar sebanyak 140 orang, denga rincian : laki-laki : 90 orang, Perempuan : 50 orang

\section{Kondisi Ekonomi KSP Suka Damai}

Kekayaan koperasi yang sebagian besar berasal dari modal sendiri jauh lebih baik bagi kesinanbungan koperasi. Hal ini tidak hanya akan memberi nilai likuiditas yang tinggi bagi koperasi juga dapat memberikan kepercayaan jaminan kepada kreditur untuk menanamkan modalnya di koperasi. Perkembangan asset KSP Suka Damai dapat dilihat pada Tabel berikut

Tabel Perkembangan aset KSP Suka Damai

\begin{tabular}{llllll}
\hline \multirow{2}{*}{$\begin{array}{l}\text { Modal } \\
\text { sendiri }\end{array}$} & 2013 & 2014 & 2015 & 2016 & 2017 \\
\cline { 2 - 6 } $\begin{array}{l}\text { Simpanan } \\
\text { pokok }\end{array}$ & 15.000 .000 & 20.000 .000 & 10.000 .000 & 20.000 .000 & 25.000 .000 \\
\hline $\begin{array}{l}\text { Simpanan } \\
\text { wajib }\end{array}$ & 5.000 .000 & $8,000.000$ & 3.000 .000 & 5.000 .000 & 10.000 .000 \\
\hline Cadangan & 20.000 .000 & 25.000 .000 & 15.000 .000 & 20.000 .000 & 30.000 .000 \\
\hline $\begin{array}{l}\text { SHU tahun } \\
\text { berjalan }\end{array}$ & 40.000 .000 & 700.000 .000 & 195.000 .000 & 500.000 .000 & $750,000,000$ \\
\hline Total modal & 80.000 .000 & 753.000 .000 & $223,000,000$ & $545,000,000$ & 815.000 .000 \\
\hline
\end{tabular}




\section{Sumber : Profil Ksp Suka Damai}

Berdasarkan Tabel diatas tampak bahwa modal sendiri KSP Suka Damai Selama lima tahun terakhir yaitu2013 sampai tahun 2017 mengalami kenaikan Total modal tertinggi terjadi pada tahun 2017, hal ini disebabkan karena semakin banyaknya anggota KSP yang aktif sehingga simpanan wajibnya menjadi semakin meningkat. Modal yang dimiliki KSP Suka Damai ini akan digunakan untuk membiayai seluruh kegiatan yang dijalankan KSP dengan tujuan pokok mensejahterakan anggotanya.

SHU merupakan sisa hasil usaha dari sebuah koperasi yang akan dibagikan kepada anggota KSP berdasarkan atas jasa dari masing-masing anggotanya. Secara umum para anggota KSP melihat perkembangan sebuah KSP

melalui besarnya SHU yang diperoleh setiap tahunnya, sebagian besar para anggota menganggap bahwa semakin besar SHU yang diperoleh, maka pengurus koperasi telah menjalankan kegiatannya dengan baik. Perkembangan SHU yang diperoleh KSP Suka Damai dapat dilihat pada Tabel 4.3

Tabel 4.3

Perkembangan SHU KSP Suka Damai dari Tahun 2013 s.d 2017

\begin{tabular}{lc}
\hline Tahun & SHU (Rp) \\
\hline 2013 & 40.000 .000 \\
\hline 2014 & 700.000 .000 \\
\hline 2015 & $195,000,000$ \\
\hline 2016 & 500.000 .000 \\
\hline 2017 & 750.000 .000 \\
\hline
\end{tabular}

Sumber :Profil KSP Suka Damai

Berdasarkan Tabel diatas SHU yang dihasilkan mengalami kenaikan dari tahun 2013 sampai 2017. Ini menunjukkan bahwa penggunaan modal sendiri sudah dikatakan berjalan dengan baik.

1. Analisis Rasio Keuangan KSP Suka Damai

Kinerja keuangan KSP Swadaya dianalisis mengambil data dari laporan keuangan (neraca dan laporan rugi-laba) selama lima tahun terakhir, yaitu tahun 2013 sampai tahun 2017. Data dianalisis berdasarkan rasio-rasio keuangan, yaitu: rasio likuiditas, rasio solvabilitas, dan rasio rentabilitas. Dalam penilaian KSP Suka Damai digunakan pedoman Klasifikasi koperasi yang dibuat oleh Kementrian Koperasi dan Usaha Kecil dan Menengah Republik Indonesia No.06/Per/M/ KUKM/V/2006

2. Rasio likuiditas

Rasio Likuiditas menunjukan kemampuan KSP Suka Damai dalam memenuhi kewajiban jangka pendek tepat pada waktunya. Hasil analisis rasio likuiditas ditunjukan oleh besar kecilnya aktiva lancar, yaitu aktiva yang mudah untuk diubah menjadi kas. Rasio yang tinggi berarti ada kelebihan dana kas atau aktiva lancar lainnya yang akan mempengaruhi profitabilitas dan rasio yang rendah berarti semakin kecilnya jaminan atas kewajiban jangka pendeknya. Berdasarkan perhitungan analisis rasio likuiditas diketahui bahwa rasio likuiditas berubah dari jangka waktu lima tahun, 
yaitu tahun 2013 sampai dengan tahun 2017. Nilai Current Ratio berkisar antara 251\% sampai dengan $216 \%$.. Hasil perhitungan Rasio dapat dilihat pada Tabel berikut

Tabel Perhitungan Analisis Rasio Keuangan Likuiditas KSP Suka Damai tahun 2013 sampai 2017

\begin{tabular}{|c|c|c|c|c|c|c|c|}
\hline Likuiditas & 2013 & 2014 & 2015 & 2016 & 2017 & Rata- & Kriteria rata- \\
\hline & & & & & & rata & rata \\
\hline Current Ratic & $107, \%$ & $109 \%$ & b $107 \%$ & $107 \%$ & $107 \%$ & $107 \%$ & Kurang baik \\
\hline
\end{tabular}

Pada Tabel diatas dapat dilihat bahwa current ratio tertinggi ada pada tahun 2013, yakni sebesar $110 \%$. Hal ini dapat diartikan bahwa kemampuan KSP SukaDamai untuk membayar hutang yang segera harus dipenuhi dengan aktiva lancar adalah setiap Rp 100 hutang lancar dijamin oleh aktiva lancar sebesar Rp.108. Pada KSP Suka Damai perkembangannya berfluktuasi di tiap tahunnya, kecuali di tahun 2013, keadaan menunjukan penurunan dibanding tahun 2017 itu disebabkan KSP menambah hutang lancarnya jauh lebih besar dari tambahan aktiva lancar. Berdasarkan angka-angka ini dapat dilihat upaya dari pihak manajeman untuk mengurangi hutang lancarnya untuk mempertahankan current rationya tetap baik

4. Rasio Solvabilitas

Rasio Solvabilitas menunjukan kapasitas KSP Swadaya untuk memenuhi kewajiban jangka pendek maupun jangka panjang. Rasio ini menyangkut jaminan, yang mengukur seberapa jauh KSP Suka Damai dibiayai pihak luar (kreditur). Rasio ini juga menunjukan proporsi atas penggunaan investasi untuk membayar hutangnya. Semakin tinggi rasio ini maka semakin besar resiko yang dihadapi dan investor akan meminta tingkat keuntungan yang semakin tinggi. Hasil perhitungan analisis rasio solvabilitas menunjukan bahwa rasio solvabilitas, mengalami berfluktuasi dalam jangka lima tahun, yaitu tahun 2013 sampai tahun 2017. Nilai Total Debt to Total Asset Ratio berkisar antara $38 \%$ sampai dengan $44 \%$. Nilai rasio solvabilitas dapat dilihat pada Tabel berikut

Tabel Perhitungan Analisis Rasio Keuangan Solvabilitas KSP Suka Damai tahun 2013 sampai 2017

\begin{tabular}{lccccccc} 
Solvabilitas & $\mathbf{2 0 1 3}$ & $\mathbf{2 0 1 4}$ & $\mathbf{2 0 1 5}$ & $\mathbf{2 0 1 6}$ & $\mathbf{2 0 1 7}$ & Rata- & Kriteria \\
\hline & & & & & & rata & rata- rata \\
\hline $\begin{array}{l}\text { Total Debt } \\
\text { Asset Ratio to Total }\end{array}$ & $50, \%$ & $51 \%$ & $51 \%$ & $54 \%$ & $52 \%$ & Baik
\end{tabular}

Pada Tabel 4.4 menunjukkan Ratio tertinggi terjadi pada tahun 2017 yaitu sebesar 54\%,dan terendah pada tahun 2014 sebesar $50 \%$ Hal ini berarti semakin kecil resiko yang dihadapi KSP Suka Damai. Lain kata bahwa Koperasi Suka Damai mampu mengatasi total hutangnya. Walaupun terjadi kenaikan total hutang tetapi diimbangi dengan peningkatan total aktiva yang cukup besar.

5. Rasio Rentabilitas

1. Return of Equity 
Rasio ini mengukur seberapa besar kemampuan KSP Suka Damai dalam memperoleh laba dalam hubungannya pendapatan, asset, maupun laba bagi modal sendiri. Rasio ini digunakan untuk mengukur hasil akhir dari sejumlah kebijaksanaan dan keputusan-keputusan yang dibuat oleh tim manajemen KSP Suka Damai. Efektifitas manajemen meliputi kegiatan fungsional manajemen seperti keuangan,pemasaran, sumberdaya manusia dan operasional. Analisa rasio rentabilitas dapat memberikan gambaran kemampuan manajemen KSP Suka Damai dalam memperoleh keuntungan.

Perhitungan analisa rasio rentabilitas ini menunjukkan bahwa rasio rentabilitas berfluktuatif dalam jangka waktu lima tahun, yaitu tahun 2013 sampai dengan tahun 2017. Nilai return of equity berkisar antara $1.04 \%$ sampai dengan $1.23 \%$ Hasil perhitungan analisis ini dapat dilihat pada Tabel 4.6

Tabel 4.6 Perhitungan Analisis Rasio Keuangan Rentabilitas KSP Suka Damai Tahun2013 sampai 2017

\begin{tabular}{lccccccc}
\hline Profitabilitas & $\mathbf{2 0 1 3}$ & $\mathbf{2 0 1 4}$ & $\mathbf{2 0 1 5}$ & $\mathbf{2 0 1 6}$ & $\mathbf{2 0 1 7}$ & $\begin{array}{c}\text { Rata- } \\
\text { rata }\end{array}$ & $\begin{array}{c}\text { Kriteria } \\
\text { rata-rata }\end{array}$ \\
\hline Return of Equity & 6,27 & 5,79 & 6,64 & 7,84 & 7,62 & 6,83 & Kurang baik \\
\hline
\end{tabular}

Sumber : Diolah dari Data Sekunder

Dari Tabel diatas menunjukkan bahwa keuntungan tertinggi terjadi pada tahun 2016 dan terendah pada tahun 2014. Kenaikan yang terjadi pada tahun 2017 ini dipengaruhi oleh kenaikan SHU setelah pajak yangg begitu besar dibandingkan dengan kenaikan modal sendiri.

\section{KESIMPULAN}

Berdasarkan pembahasan hasil penelitian yang telah dikemukakan di bab sebelumnya maka dapat disimpulkan dari hasil penelitian ini sebagai berikutKinerja KSP Suka Damai selama lima tahun terakhir, yaitu tahun 2013 sampai tahun2017 pada umumnya baik artinya sudah memenuhi kriteria yang sangat bagus Perkembangan rasio likuiditas, solvabilitas, profitabilitas pada KSP Suka Damai dari tahun 2013 sampai tahun 2017 adalah sebagai berikut.

a. Kinerja likuiditas kurang baik berdasarkan perhitungan rasio likuiditas 20132017 nilai yang dicapai pada umumnya kurang baik lebih berada diantara 108\% sampai $110 \%$ sesuai dengan klasifikasi koperasi. Hal ini menunjukkan bahwa cadangan dan dana jangka pendek sudah berkembang untuk membangun koperasi.. Nilai current ratio tahun 2017 merupakan tahun yang tertinggi yaitu sebesar $110 \%$ dan nilai terendah sebesar 108\%. Pada tahun 2016

b. Nilai solvabilitas KSP Suka Damai 2013-2017.dalam menjamin hutang dengan modal sendiri adalah baik ( antara 50\% dan 51\%), dengan rasio tertinggi pada tahun 2013 sebesar 54\% dan dan terkecil tahun 2014 sebesar 50\%

c. Rentabilitas KSP Suka Damai tahun 2013-2017 menunjukkan nilai yang cukup baik yaitu berada diantara nilai $6 \%-8 \%$ tapi masih dikatakan kurang dari target baik. Nilai return of equity tertinggi pada tahun 2013 yaitu sebesar $7.84 \%$ dan terendah tahun 2016 yang hanya sebesar 5.796\%. Secara keseluruhan dapat dikatakan untuk rasio-rasio ini cukup baik. 


\section{DAFTAR PUSTAKA}

Agnes Swair, 2011. kondisi keuangan dan prestasi perusahaan; . Edisi Pertama. Cetakan Kedua. Yogyakarta: EKONISIA.

Alphasti Rasi Destiadi 2010 Menjelaskan macam macam tipe dari perusahaan

Arifin, J. 2007. Cara Cerdas Menilai Kinerja Perusahaan (Aspek Finansial dan Non Finansial) Berbasis Komputer. Elex Media Komputindo. Jakarta.

Alphasti Rasi Destiadi 2010 menjelaskan tentang bentuk laporan keuangan dalam perusahaan

Ali Arifin. 2007. Membaca Saham. Yogyakarta: Andi.

Anonim. 2008. Rasio Finansial. http://wikipedia.id.org. Diakses tanggal 31Januari 2009.

Alphasti Rasi Destiadi 2010 Menjelaskantentang pengertian dari kewajiban lancer

Anonimus. 1997. Undang-undang No. 25 Tahun 1992 tentang Perkoperasian (dilengkapi dengan UU No. 12 tahun 1967 tentang Pokok-pokok Perkoperasian). Jakarta: Aneka Ilmu.

Bambang, Riyanto. 2001. Dasar-dasar Pembelajaran Perusahaan. Yogyakarta: BPFE.

Baridwan, Zaki. 2004. Intermediete Accounting. Yogyakarta: BPFE. C.Van Home, James. 2008. Prinsip-prinsip Manajeman Keuangan. Edisi Ketujuh.Jakarta: Salemba Empat

C.Van Home, James. 1997. Prinsip-prinsip Manajeman Keuangan. Edisi Ketujuh.Jakarta: Salemba Empat.

Frans Novi Hardi. 2011. Analisis Kinerja Ekonomi Keuangan Pada Koperasi Kerinci Gitman, Lawrence J. (2003). Principles of Managerial Finance. Boston: Pearson Addison Wesley Jumingan.2006. Analisis Laporan Keuangan. Jakarta: Bumi Aksara

Kadaran 2009 menjelaskan bahwa laporan laba rugi untuk mengetahui keberhasilan atau kegagalan jalannya suatu perusahaan

Kadarsan, H.W. 1992. Keuangan Pertanian dan Pembiayaan Perusahaan Agribisnis. Jakarta: Gramedia Pustaka Utama.

Kamsir, 2008. Manajemen Perbankan. Jakarta: Raja Grafindo Persada.

Kasmir, 2008. Analisis Laporan Keuangan. Jakarta: Raja Grafindo Persada.

Keputusan Menteri Negara Koperasi dan UKM No.06/Per/M/KUKM/V/2006.

Munawir 2010 Menjelaskan tentan Rasio Likuiditas,Solvabilita dan Rentabilitas

Pasal 4 UU no. 25 Tahun 1992 menjelaskan tentang perkoperasian fungsi dan peran koperasi

Pasal 16 UU No 25 tahun 1992 tentang Penggolongan Koperasi.

Pasal 33 Undang-Undang Dasar 1945 tentang Pengkoperasian.

Sartono, Agus. 2006. Manajemen Keuangan dan Aplikasi, edisi 4. BPFE, Yogyakarta. Soedoyono. 1991. 